\title{
Anaemia of chronic disease in rheumatoid arthritis: effect of the blunted response to erythropoietin and of interleukin 1 production by marrow macrophages
}

\author{
M A Smith, S M Knight, P J Maddison, J G Smith
}

\begin{abstract}
Anaemia in rheumatoid arthritis (RA) is a common and debilitating complication. The most common causes of this anaemia are iron deficiency and anaemia of chronic disease. Investigations have suggested that interleukin 1 (IL-1) or tumour necrosis factor (TNF), or both, from monocytes associated with chronic inflammation are responsible for the anaemia of chronic disease. On bone marrow examination anaemia of chronic disease is characterised by the diversion of iron from the erythropoietic compartment into marrow macrophages. This phenomenon is termed failure of iron utilisation.
\end{abstract}

In this study, CFU-E (colony forming unit erythroid; late red cell precursors) and BFU-E (burst forming unit erythroid; early red cell precursors) stem cells were cultured from 10 normal marrow samples and 12 marrow samples from patients with $R A$ with iron deficiency anaemia and 10 samples from patients with RA with failure of iron utilisation. All patients with RA were anaemic (haemoglobin $<100 \mathrm{~g} / \mathbf{l})$, Potential accessory or inhibitory cells of erythropoiesis (CD4, CD8, or CD14 positive cells) were removed before culture. Control marrow samples were studied in a similar manner. Normal marrow samples yielded 377 (17) CFU-E and 133 (6) BFU-E (mean (SD)) colonies for each $2 \times 10^{5}$ light density cells plated. CD4 ablation caused reductions of 62 and $100 \%$ in CFU-E and BFU-E colonies respectively. CD14 removal resulted in considerable but lesser reductions of $46 \%$ for CFU-E and $25 \%$ for BFU-E. In both groups of patients with RA, CFU-E colony numbers were significantly lower than those seen in normal control subjects, 293 (17) for patients with iron deficiency anaemia and 242 (35) for patients with failure of iron utilisation. BFU-E colony numbers were 102 (13) and 108 (20) respectively. In patients with RA, CD4 removal caused a significantly greater loss of CFU-E colonies compared with normal control subjects. Cytolysis of CD14 positive cells caused a reduction in CFU-E colonies in the two RA groups which was similar to that seen in normal subjects. In conclusion, patients with RA seem to have fewer CFU-E progenitors but essentially normal numbers of BFU-E stem cells. Our data suggest a stimulatory role for marrow CD4 and CD14 cells in erythropoiesis in patients with RA. Monocytes-macrophages (CD14 positive) are known to be producers of IL-1 or TNF, or both, however, the predicted increase in the CFU-E colonies on removal of
CD14 cells is not seen. Therefore, if IL-1 or TNF, or both, are responsible for the impairment of erythropoiesis in patients with $R A$, marrow macrophages are unlikely to be the source. Moreover, these results indicate the probability of erythropoietin resistance on the basis of diminished CFU-E colony formation in patients with RA.

Active rheumatoid arthritis (RA) is often associated with anaemia, which may be accounted for by iron deficiency or less often by reduced vitamin B-12 or folic acid levels, or both. An equally common cause is the anaemia associated with chronic disease. Many theories have been proposed to explain possible mechanisms underlying this disorder, but the pathogenesis of the anaemia of chronic disease is still unclear.

Previous studies have shown a variety of potential contributory factors. It has been shown that patients with RA with anaemia of chronic disease can have impaired iron uptake and transferrin binding by erythroblasts. ${ }^{1}$ Baer et al have suggested the possibility of a blunted response to erythropoietin. ${ }^{2}$ Altered red cell kinetics have been implicated, including haemolysis and reduced red cell lifespan. ${ }^{3}$ This latter observation could be associated with an increase in phagocytic activity by activated macrophages. Disturbances in iron metabolism have often been noted in patients with $R A$, including diversion of iron into marrow macrophages and consequent hypoferraemia. This is likely to be the result of lactoferrin production by the secondary granules of neutrophils or the induction of apoferritin synthesis. ${ }^{45}$ Impaired iron absorption has been reported as a contributory factor by some workers, ${ }^{6}$ but challenged by others. ${ }^{7}$ Benn et al showed that in active RA, the absorption of iron is actually increased to compensate for iron deficiency. The iron surplus thus generated is reliably reflected by the amount of iron found in marrow macrophages. Attempts have been made to link the occurrence of the anaemia of chronic disease with the insufficient production of erythropoietin. Biregard et $a l^{8}$ concluded that serum erythropoietin levels are increased in $\mathrm{RA}$ in response to the degree of anaemia. Conversely, Baer et al suggest that suppressed erythropoiesis may be in part due to reduced erythropoietin. ${ }^{2}$ Serum inhibitors of erythropoiesis have been detected in patients with RA. ${ }^{9}$ Studies have examined the possibility that interleukin 1 (IL-1) ${ }^{11}$ or tumour necrosis factor (TNF), ${ }^{12}$ or both, may be involved in the 
suppression of erythropoiesis in patients with RA.

Given the considerable debate which exists about the underlying mechanism of the anaemia of chronic disease, the aim of this study was to compare in vitro the erythropoietic capacity of patients with RA with that of normal subjects at the burst forming unit erythroid (BFU-E) and colony forming unit erythroid (CFU-E) stem cell levels. BFU-E are in vitro colonies of immature erythroblasts, whereas CFU-E comprise more mature precursors. These colony types represent a progression in red cell differentiation. It is known that CD4 lymphocytes are the major source of burst promoting activity which is fundamental to the formation of BFU-E in vitro and in vivo. In a rare subgroup of patients with RA, CD8 lymphocytes have been shown to cause inhibition of haemopoiesis, including in some instances erythropoiesis. ${ }^{1314} \mathrm{CD} 14$ positive cells are a potential source of IL-1 or TNF, or both (cytokines which have been implicated as causing the anaemia of chronic disease). Thus these immunologically identifiable cells can exert accessory or inhibitory effects on erythropoiesis. The selective cytolysis of these subpopulations before clonogenic culture thus allows speculation about possible factors affecting the modulation of erythropoiesis at the cellular level in patients with RA.

\section{Patients and methods}

PATIENT GROUPS AND MARROW SAMPLING

Marrow samples were aspirated from the posterior iliac crests or sterna of patients with RA with either iron deficiency anaemia (12 patients) or failure of iron utilisation (ten patients). Control marrow samples were obtained from ten patients undergoing diagnostic aspiration in whom haemopoiesis was normal and in whom no inflammatory condition was present.

Patients with RA were included in the study if they had anaemia (haemoglobin $<100 \mathrm{~g} / \mathrm{l}$ ), no evidence of B-12 or folic acid deficiency, nor of thyroid or renal dysfunction. Patients were excluded if they were receiving cyclophosphamide or azathioprine as these drugs are known to interfere with bone marrow culture. Table 1 gives the clinical details of patients in this study. Patients with RA were defined as having anaemia of chronic disease when bone marrow examination showed excessive extra haemoglobin iron localised within marrow macrophages (Perls' stain). Patients with RA were defined as having iron deficiency when no stainable iron was observed in the marrow sample.

\section{CULTURE OF CFU-E AND BFU-E ERYTHROID} PRECURSORS

Light density marrow cells were obtained by density centrifugation (sp. gr. 1·077). Light density marrow cells were cultured in triplicate at a final concentration of $2 \times 10^{5}$ cells $/ \mathrm{ml}$. Briefly, cells were cultured in supplemented Dulbecco's minimal essential medium with $0.8 \%$ methylcelluose, $10 \%$ fetal calf serum, $20 \%$ human serum, $10 \%$ PHA lymphocyte conditioned medium, $5 \times 10^{-4} \mathrm{M} \beta$-mercaptoethanol, and $1 \mathrm{U} / \mathrm{ml}$ recombinant human erythropoietin (Amersham, Bucks, United Kingdom).

In some cultures indomethacin (Sigma, United Kingdom) was included at a final concentration of $10^{-5} \mathrm{~mol} / \mathrm{l}$. CFU-E and BFU-E colonies were enumerated on days 5 and 14 respectively.

\section{CYTOLYTIC REMOVAL OF SUBPOPULATIONS OF} LIGHT DENSITY MARROW CELLS

Before culture at $2 \times 10^{5}$ light density marrow cells per ml, CD4, CD8, or CD14 positive cells were removed from the marrow samples using complement fixing monoclonal antibodies and DR typing grade rabbit complement (Pelfreez, Northeast Biomedicals, Uxbridge, United Kingdom). The method has been described elsewhere. ${ }^{15}$ The following monoclonal antibodies were used: OKT4a (Ortho UK), $\mathrm{RFT}_{8}$ : IgM subtype (department of immunology, Royal Free Hospital, London, United Kingdom) and $\mathrm{Mo}_{2}$ (Coulter Clone). These monoclonal antibodies identify CD4, CD8, and CD14 positive cells respectively. Complement controls were always included.

\section{STATISTICS}

Intragroup and intergroup statistical analyses of significance were performed using two sample paired and non-paired $t$ tests respectively.

\section{Results}

Table 2 compares the erythroid colony activity in patients with RA with that in normal subjects. CFU-E levels are significantly impaired in patients with $\mathrm{RA}$ with iron deficiency anaemia and failure of iron utilisation $(p=0.002$ and 0.004 respectively). BFU-E levels are
Table 1 Clinical details for patients with rheumatoid arthritis $(R A)$. Results given as mean $(S E)$

\begin{tabular}{lcc}
\hline Clinical parameter $^{*}$ & $R A+I D A^{*}$ & $R A+F I U^{*}$ \\
\hline Hb $(\mathrm{g} / \mathrm{l})$ & $86 \cdot 9(3 \cdot 7)$ & $88 \cdot 8(2 \cdot 3)$ \\
MCV (fl) & $71 \cdot 3(2 \cdot 0)$ & $73 \cdot 2(1 \cdot 5)$ \\
Ferritin $(\mu \mathrm{g} / \mathrm{l})$ & $14 \cdot 7(4 \cdot 0)$ & $135 \cdot 6(33 \cdot 4) \dagger$ \\
PVisc (mPa) & $1 \cdot 91(0 \cdot 07)$ & $2 \cdot 07(0 \cdot 06)$ \\
No positive for RF & 9 & 6 \\
No receiving DMD & 8 & 7
\end{tabular}

No receiving DMD

*(IDA) iron deficiency anaemia; (FIU) failure of iron utilisation (Hb) haemoglobin; (MCV) mean corpuscular volume; (PVisc) (Hb) haemoglobin; (MCV) mean corpuscular volume; (PVisc)
plasma viscosity; (RF) rheumatoid factor; (DMD) disease modifying drugs.
$t \mathrm{p}<0.001-0.003$.

Table 2 Comparison of erythroid colony activity in normal subjects and patients with rheumatoid arthritis $(R A)$. Results given as mean (SE) per $2 \times 10^{5}$ light density marrow cells in triplicate cultures

\begin{tabular}{|c|c|c|}
\hline Patient groups & $\begin{array}{l}\text { CFU-E } \\
\text { stem cells }\end{array}$ & $\begin{array}{l}B F U-E \\
\text { stem cells }\end{array}$ \\
\hline \multirow{3}{*}{$\begin{array}{l}\text { Control subjects }(\mathrm{n}=10) \\
\text { Patients with RA (IDA) } \\
(\mathrm{n}=12)^{*} \\
\text { Patients with RA (FIU) } \\
(\mathrm{n}=10)^{*}\end{array}$} & 377 (17) & $133(6)$ \\
\hline & $293(17)$ & $102(13)$ \\
\hline & 242 & $108(20)$ \\
\hline
\end{tabular}

*(IDA) iron deficiency anaemia; (FIU) failure of iron utilisation. 
Table 3 Part played by accessory cells in erythropoiesis in normal subjects and patients with rheumatoid arthritis (RA). Results are mean (SE) colony numbers per $2 \times 10^{5}$ light density marrow cells in triplicate cultures. For each of these samples the percentage reduction accompanying a cytolytic step was calculated. The significance values for comparisons between colony numbers with and without monoclonal antibody manipulations are given

\begin{tabular}{|c|c|c|c|c|c|c|c|c|c|}
\hline \multirow[t]{2}{*}{ Culture conditions } & \multicolumn{3}{|c|}{ Normal subjects $(n=10)$} & \multicolumn{3}{|c|}{ Patients with $R A$ and II)A $(n=12)$} & \multicolumn{3}{|c|}{ Patients with RA and FIU $(n=10)$} \\
\hline & $\overline{C F U-E}$ & $\begin{array}{l}\text { Mean } \\
\text { reduction (\%) }\end{array}$ & p Value & $C F U-E$ & $\begin{array}{l}\text { Mean } \\
\text { reduction (\%) }\end{array}$ & p Value & $C F U-E$ & $\begin{array}{l}\text { Mean } \\
\text { reduction ( } \%)\end{array}$ & p Value \\
\hline $\begin{array}{l}C F U-E \\
\text { C control } \\
\text { CD4 cells } \\
\text { CD8 cells } \\
\text { CD14 cells }\end{array}$ & $\begin{array}{l}377 \pm 17 \\
139 \pm 8 \\
379 \pm 11 \\
203 \pm 9\end{array}$ & $\begin{array}{l}62 \% \\
0 \% \\
45 \%\end{array}$ & $\begin{array}{l}\mathrm{p}<0.001 \\
\mathrm{p}=0.872 \\
\mathrm{p}<0.001\end{array}$ & $\begin{array}{r}293 \pm 17 \\
70 \pm 12 \\
280 \pm 15 \\
136 \pm 20\end{array}$ & $\begin{array}{l}75 \% \\
3 \% \% \\
54 \%\end{array}$ & $\begin{array}{l}\mathrm{p}<0.001 \\
\mathrm{p}=0.293 \\
\mathrm{p}<0.001\end{array}$ & $\begin{array}{r}242 \pm 35 \\
49 \pm 26 \\
195 \pm 27 \\
162 \pm 22\end{array}$ & $\begin{array}{l}86 \% \\
18 \% \\
32 \%\end{array}$ & $\begin{array}{l}\mathrm{p}<0.001 \\
\mathrm{p}=0.034 \\
\mathrm{p}<0.004\end{array}$ \\
\hline $\begin{array}{l}B F U-E \\
\text { C control } \\
\text { CD4 cells } \\
\text { CD8 cells } \\
\text { CD14 cells }\end{array}$ & $\begin{array}{l}133 \pm 6 \\
0 \pm 0 \\
108 \pm 5 \\
99 \pm 6\end{array}$ & $\begin{array}{l}99 \cdot 7 \% \\
17 \% \\
25 \%\end{array}$ & $\begin{array}{l}p<0.001 \\
p=0.008 \\
p<0.001\end{array}$ & $\begin{array}{l}102 \pm 13 \\
20 \pm 5 \\
79 \pm 12 \\
57 \pm 8\end{array}$ & $\begin{array}{l}84 \% 11 \\
10 \% 1 \\
30 \%\end{array}$ & $\begin{array}{l}\mathrm{p}<0.001 \\
\mathrm{p}=0.116 \\
\mathrm{p}<0.005\end{array}$ & $\begin{array}{l}108 \pm 20 \\
12 \pm 6 \\
34 \pm 10 \\
64 \pm 16\end{array}$ & $\begin{array}{l}92 \% \\
76 \% \\
56 \%\end{array}$ & $\begin{array}{l}\mathrm{p}<0.001 \\
\mathrm{p}<0.001 \\
\mathrm{p}<0.001\end{array}$ \\
\hline
\end{tabular}

(IDA) iron deficiency anaemia; (FIU) failure of iron utilisation.

slightly, but not significantly, lower in the rheumatoid groups compared with normal subjects.

Table 3 shows the effects of cytolysis of potential accessory cells of erythropoiesis from marrow light density cell preparations before culture. In marrow samples from patients with $\mathrm{RA}$ and normal subjects removal of CD4 positive cells had a deleterious effect on subsequent CFU-E and BFU-E formation. The reduction in erythroid colony formation was significantly more profound in patients with RA compared with normal subjects following CD4 cell ablation $(p<0.05$ and $p<0.004$ for patients with RA with iron deficiency anaemia and failure of iron utilisation compared with normal subjects respectively). CD8 cell cytolysis was found to have a significant effect on each stage of erythropoiesis in the group with failure of iron utilisation. As expected, CD4 cell removal had an especially dramatic effect on BFU-E numbers in all groups. CD14 cell removal was consistently detrimental to CFU-E and BFU-E formation in all groups. Intergroup comparisons showed no difference in the extent of reductions in CFU-E colony formation following CD14 cytolysis. However, the percentage decrease in BFU-E numbers was significantly greater in the group with failure of iron utilisation compared with normal subjects $(\mathrm{p}<0 \cdot 014)$.
The figure shows the effects of selective cytolysis of subpopulations of mononuclear cells on erythropoiesis in the three groups studied.

\section{Discussion}

This study shows that the in vitro erythropoietic capacity of marrow from patients with RA is significantly impaired at the CFU-E level compared with normal subjects. CFU-E cells appear at day 4 or 5 of culture and comprise the immediate precursors of pronormoblasts. The more primitive erythroblast colonies (BFU-E) which were enumerated on day 14 of culture are similar in number to those of normal subjects. Previous studies by other workers have shown reduced BFU-E numbers in patients with RA and anaemia of chronic disease compared with non-anaemic subjects. ${ }^{16}$

The development of CFU-E from BFU-E stem cells and subsequent differentiation into more mature red cells is dependent on erythropoietin. ${ }^{1718}$ Red cell divisions at the primitive BFU-E stage are dependent on burst promoting activity, a major component of which is interleukin 3 (IL-3). ${ }^{19} 20$ Interleukin 3 may also affect later stages of erythroid development. ${ }^{1921}$ The fact that CFU-E rather than BFU-E numbers were significantly decreased in patients with RA suggests that there may be reduced
Percentage reduction in colony formation following removal of subpopulations of mononuclear cells. (A) Colony forming unit erythroid; $(B)$ burst forming unit erythroid. IDA = iron deficiency anaemia; $F I U=$ failure of iron $F I U=$ fail
utilisation.
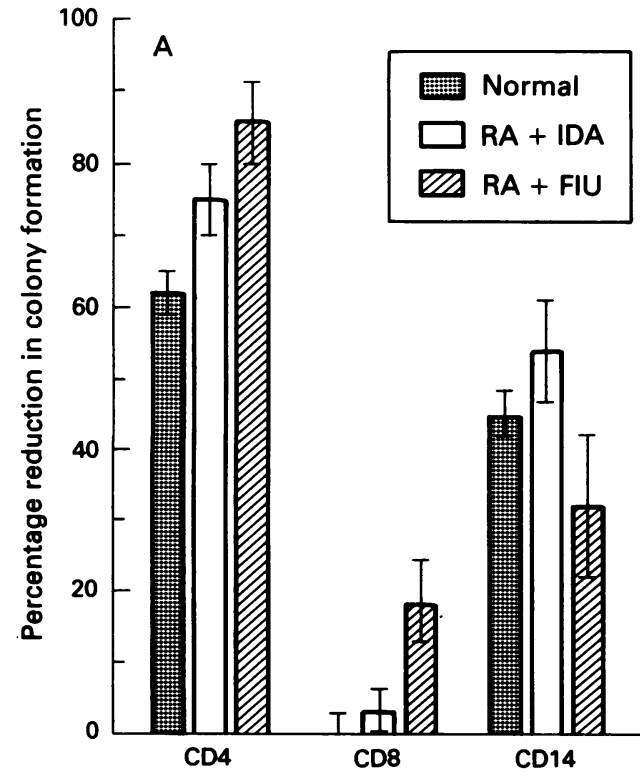

60

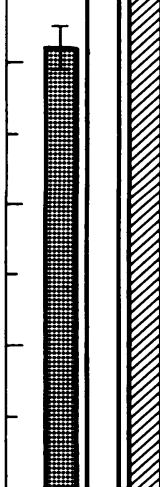

CD4

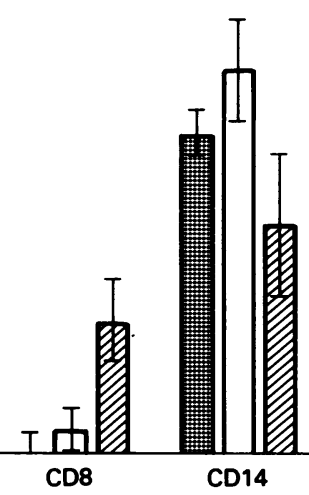


production of erythropoietin or an impaired response to this cytokine on the part of the CFU-Es in patients with RA.

Iron deficiency in RA may result from gastrointestinal blood loss, or from inadequate dietary intake. Nonetheless, defective CFU-E formation was also noted in patients with iron deficiency anaemia as well as those with failure of iron utilisation, suggesting that blood loss is not entirely responsible for their anaemia.

As a result of their potential influence on erythropoiesis, CD4 and CD8 lymphocytes and monocytes were studied by selective cytolytic manipulation of marrow cells before culture. Cytolysis of CD4 positive cells before the culture of light density marrow cells greatly reduced BFU-E colony formation, presumably as a consequence of diminished burst promoting activity production. Interleukin 3 has a stimulatory effect on monocyte-macrophages in addition to its effect on BFU-E. ${ }^{20-22}$ CFU-E numbers were reduced to a lesser but still significant extent after CD4 cytolysis. This increased dependence of CFU-E cell precursors on CD4 cells in patients with RA compared with normal subjects possibly represents a compensatory mechanism acting in the presence of suboptimal circumstances for erythropoiesis.

Red cell development represents a continuum, thus a small proportion of the haemoglobinised colonies enumerated on day 5 might have been small, early appearing bursts (mature BFU-Es which are dependent on erythropoietin). If so, CD4 cytolysis would have reduced this population.

CD8 positive cells have been shown to inhibit various aspects of haematopoiesis, including erythropoiesis, in patients with RA and chronic $\mathrm{T}$ cell lymphocytosis. ${ }^{14} 15$ This study included an investigation of these cells as potential inhibitors of red cell development in RA. We are unaware of a part for CD8 positive cells in normal erythropoiesis, but note that their removal had a significantly deleterious effect on red cell colony formation in patients with RA and failure of iron utilisation. These cells possibly have a supportive part to play in the fragile erythropoiesis seen in such patients.

Monocytes appear to be supportive in erythroid colony formation in all groups. In contrast, Roodman et al $^{23}$ showed an increase in BFU-E stem cells following monocyte removal by adherence to plastic. As they report improbably high monocyte percentages in marrow (40 (5)\% for normal subjects, 44 (8)\% and $38(8) \%$ for non-anaemic and anaemic patients with RA respectively), however, their results must be interpreted with caution. Conversely, Gordon et al ${ }^{24}$ have shown that bone marrow monocytes normally stimulate erythroid colony formation.

In summary, on the basis of our experimental data, CD4 lymphocytes and monocytes both have major supportive roles to play in erythropoiesis in normal subjects and patients with RA.

It has been suggested that IL-1 ${ }^{12}$ and TNF ${ }^{13}$ are humoral inhibitors of erythropoiesis in patients with RA. It must be borne in mind that the effects of IL-1 on haematopoiesis are complex. Marrow fibroblasts and stromal cells are induced by IL-1 to produce granulocytemacrophage and granulocyte colony stimulating factors, ${ }^{25-27}$ which can stimulate the growth of BFU-E. ${ }^{20}$ Thus IL-1 might provide stimulatory and inhibitory signals to erythropoietic progenitors. If IL-1 derived from marrow macrophages is a major factor in the inhibition of erythropoiesis, we would have expected an increase in erythropoiesis following the cytolysis of CD14 positive cells. In reality a reduction was observed. As light density marrow cells receive a total of four washes before culture, any exogenous IL-1 or TNF previously present would certainly have been removed. Therefore we can assume that IL-1 mediated inhibition of erythropoiesis is not part of the function of marrow macrophages.

Tumour necrosis factor does not affect erythropoietin induced erythroid differentiation as shown by Schooley et $a{ }^{28}$ The principal haematological effects of TNF are the activation of macrophages, granulocytes, and cytotoxic cells, in addition to increasing leucocyte and endothelial cell adhesion. ${ }^{29}$ These biological activities should have no effect on erythropoiesis.

The synthesis of erythropoietin occurs primarily in the kidney ${ }^{30}$ in response to lowered tissue oxygen tension. Erythropoietin is reported to be produced in marrow macrophages, ${ }^{31-34}$ thus cytolysis of $\mathrm{CD} 14$ positive cells would be expected to have a deleterious effect on CFU-E formation, as is indeed shown by our data. Additionally, granulocyte-macrophage colony stimulating factor produced by monocytemacrophages has been shown to initiate or support erythroid colony formation. ${ }^{10} \quad 20 \quad 24 \quad 35-37$ The marrow monocyte-macrophage is an extremely complex cell performing a myriad of functions in haematopoiesis. Although these cells may be regarded as a source of potential inhibitors of erythropoiesis we have found that their overall effect is stimulatory.

Owing to the important part played by nonsteroidal anti-inflammatory drugs (NSAIDs) in the management of $R A$, we examined the possible contribution of these drugs to the anaemia of RA by looking at the effect of indomethacin on erythroid colony numbers. Our data (not shown) showed no difference when indomethacin $\left(10^{-5} \mathrm{~mol} / \mathrm{l}\right)$ was present in culture. It is therefore unlikely that NSAIDs exert a direct inhibitory effect on erythropoiesis.

Our study considers erythropoiesis in RA at two levels of development of red cell precursors, unlike previous in vitro studies which focused on BFU-E stem cells alone. ${ }^{11}{ }^{16}$ CFU-E stem cells are a critical stage in the marrow response to anaemia as they are highly dependent on erythropoietin. Our data showed a significant impairment of CFU-E formation in RA. This finding leads us to question whether an aberration in either erythropoietin response or production could be contributing in part to the disordered erythropoiesis observed in patients with RA. Previous studies present conflicting evidence about the effectiveness of erythropoietin secretion in active RA. ${ }^{38-40}$ As we cultured marrow samples from normal subjects and patients with RA with identical amounts of erythropoietin, 
which had been shown to be sufficient for effective erythropoiesis in normal marrow samples, it is likely that marrow from patients with RA does show a blunted response to erythropoietin at the CFU-E level. As our culture system does not include supraoptimal concentrations of erythropoietin, it is possible that marrow macrophages are further contributing to in vitro levels of erythropoietin. The mechanisms underlying the anaemia of chronic disease are likely to be several and complex. The sequestration of iron by marrow macrophages seen in the failure of iron utilisation must also be a contributory factor in the pathogenesis of anaemia in these patients. In the failure of iron utilisation iron is unavailable for erythropoiesis due to its impaired release from the monocyte-macrophage system to circulating transferrin. Within this system iron is bound to apoferritin for which is has a higher afffinity than for transferrin. As apoferritin is an acute phase reactant protein and its synthesis is stimulated by IL-1, it has been proposed that iron is immobilised by increased intracellular concentrations of apoferritin in inflammatory disorders. $^{6}$ Our analysis of erythropoiesis at stem cell level in patients with RA, combined with in vitro cytolysis, has allowed scrutiny of the functional parts played by potential accessory cells. The data from this study re-enforce the contention that RA erythroblasts have a blunted response to erythropoietin at the CFU-E level. Finally, IL-1 may be a contributor to the pathogenesis of anaemia of chronic disease in patients with RA, but its principal production site does not encompass marrow monocytes.

1 Vreugdenhil G, Kroos M J, van Eijk H G, Lowenberg B, Swaak A J G. Impaired iron uptake and transferrin binding by erythroblasts in the anaemia of rheumatoid arthritis. $\mathrm{Br}$ by erythroblasts in the anaemia
R Reumatol $1990 ; 29: 335-9$.

2 Baer A N, Desspris E N, Goldwasser E, Krantz S B. Blunted erythropoietin response to anaemia in rheumatoid arthritis. Br F Haematol 1987; 66: 559-64.

3 Dinant $\mathrm{H}$ J, de Maat C E M. Erythropoiesis and mean redcell lifespan in normal subjects and in patients with the anaemia of active rheumatoid arthritis. Brf Haematol 1987 39: $437-40$.

4 Konijn A M, Hershko C. Ferritin synthesis in inflammation. I. Pathogenesis of impaired iron release. $\mathrm{Br} \mathcal{F}$ Haematol 1977; 37: 7-16.

5 Van Shick J L, Masson P L, Heremans J F. The involvement of lactoferrin in the hyposiderinemia of acute inflammation. F Exp Med 1974; 140: 1068

6 Weber J, Werre J M, Julius H W, Marx J J M. Decreased iron absorption in patients with active rheumatoid arthritis iron absorption in patients with active rheumatoid arthritis
with and without iron deficiency. Ann Rheum Dis 1988; 47: with and

7 Benn H P, Drew J, Randzio G, Jensen J M, Loffler H. Does active rheumatoid arthritis affect intestinal iron absorption Ann Rheum Dis 1988; 47: 144-9.

8 Birgegard G, Hallgren R, Caro J. Serum erythropoietin in rheumatoid arthritis and other inflammatory arthritides: relationship to anaemia and the effect of anti-inflammatory treatment. Br f Haematol 1987; 65: 479-83.

9 Reid C D L, Prouse P J, Baptisa L C, Gumpel J M, Chanarin I. The mechanism of the anaemia in rheumatoid arthritis: effects of bone marrow adherent cells and of serum iron in vitro erythropoiesis. Br $\mathcal{J}$ Haematol 1984; 58: 607-15.

10 Prouse P J, Harvey A R, Bonnar B, Reid C D, Ansell B M Gumpel $M$. Anaemia in chronic juvenile arthritis: serum inhibition of normal erythropoiesis in vitro. Ann Rheum Dis 1987; 46: 127-34.

11 Maury C P J, Anderson L C, Teppo A-M, Partanen S Juvonen E. Mechanism of anaemia in rheumatoid arthritis: demonstration of raised interleukin $1 \beta$ concentrations in anaemic patients and of interleukin 1 mediated suppression of normal erythropoiesis and proliferation of erythro- leukaemia (HEL) cells in vivo. Ann Rheum Dis 1988; 47: 972-8.

12 Roodman G D. Mechanisms of erythroid suppression in the anaemia of chronic disease. Blood Cells 1987; 13: 171-84

13 Smith J G, Smith M A, James I, Blundell E, Maddison P J. Inhibition of CFU-GM by prostaglandins in a case of chronic T-cell lymphocytosis and neutropenia. $\mathrm{Br} \mathcal{F}$ Haematol 1989; 73: 148-51.

14 Newland A C, Catovsky D, Linch D C, et al. Chronic T cell lymphocytosis: a review of 21 cases. Br 7 Haematol 1984; 58: 433-46.

15 Smith J G, Seenan A K, Smith M A, et al. Cyclical neutropenia and $\mathrm{T}$-lymphocyte mediated stimulation of granulopoiesis. Br $\mathcal{F}$ Haematol 1985; 60: 481-9.

16 Harvey A R, Clarke B J, Chui D H K, Kean W F, Buchanan W W. Anemia associated with rheumatoid disease. Arthritis Rheum 1983; 26: 28-34.

17 Eaves C J, Humphries R K, Krystal G, Eaves A C. Erythropoietin action: models, data and speculation. In: Stamatoyannopoulos G, Nienhuis A W. Haemoglobins in development and differentiation. New York: Liss, 63-72.

18 Tsang F W, Aye M D. Evidence for proliferation of erythroid progenitor cells in the absence of added erythropoietin. Exp Haematol 1979; 7: 383-8.

19 Watson J D, Prestidge R L. Interleukin 3 and colony stimulating factors. Immunology Today 1983; 4: 278-80.

Sieff C A. Haemopoietic growth factors. F Clin Invest 1987; 79: 1549-57.

21 Fagg B. Is erythropoietin the only factor which regulates late erythroid differentiation? Nature 1981; 289: 184-6.

22 Goldstone A H, Khwaja A. The role of haemopoietic growth factors in bone marrow transplantation. Leuk Res 1990; 14: $721-9$.

23 Roodman G D, Horadam V W, Wright T L. Inhibition of erythroid colony formation by autologous bone marrow adherent cells from patients with the anaemia of chronic disease. Blood 1983; 62: 406-12.

24 Gordon L I, Miller W J, Branda R F, Zanjani E D, Jacob H S. Regulation of erythroid colony formation by bone marrow macrophages. Blood 1980; 55: 1047-50.

25 Fibbe W E, van Damme J, Billiau A, et al. Interleukin induces human marrow stromal cells in long term culture to produce granulocyte colony-stimulating factor and macroproduce granulocyte colony-stimulating factor and macro-

26 Fibbe W E, van Damme J, Billiau A, et al. Interleukin 1 (22-K factor) induces release of granulocyte-macrophage (22-K factor) induces release of granulocyte-macrophage colony-stimulating activity from hum

27 Kaushansky K, Lin N, Adamson J W. Interleukin stimulates fibroblasts to synthesise granulocyte-macrophage and granulocyte colony stimulating factors. $\mathcal{f}$ Clin Inves 1988; 81: 92-7

28 Schooley J C, Kullgren B, Alison A C. Inhibition by interleukin 1 of the action of erythropoietin on erythroid precursors and its possible role in the pathogenesis of hypoplastic anaemias. Br f Haematol 1987; 67: 11-7.

29 Roitt I, Brostoff J, Male D. Immuñology. 2nd ed. London: Gower Medical 1989: 9.

30 Graber S E, Krantz S B. Erythropoietin and the control of red cell production. Annu Rev Med 1978; 29: 51-66.

31 Rich I, Heit W, Kubanek B. Extrarenal erythropoietin production by macrophages. Blood 1982; 60: 1007-17.

32 Kurland J I, Meyers P A, Moore M A S. Synthesis and release of erythroid colony and burst-potentiating activities by purified populations of murine peritoneal macrophages. F Exp Med 1980; 151: 839-52.

33 Zuckerman K S. Human erythroid burst-forming units: growth in vitro is dependent on monocytes but not $T$ lymphocytes. F Clin Invest 1981; 67: 702-9.

34 Rich I N. The macrophage as a production site for haemopoietic regulator molecules: sensing and responding to normal and pathophysiological signals. Anticancer Res 1988; 8: $1015-40$.

35 Migiaccio G, Migliacco A R, Adamson J W. In vitro differentiation of human granulocyte/macrophage and erythroid progenitors: comparative analysis of the influence of recombinant human erythropoietin, G-CSF, GM-CSF of recombinant human erythropoietin, G-CSF, GM-CSF
and IL-3 in serum-supplemented and serum deprived and IL-3 in serum-supplemented

36 Metcalf D, Begley C G, Johnson G R, et al. Biologic properties in vitro of a recombinant human granulocyte macrophage colony stimulating factor. Blood 1986; 67: $37-45$

37 Tomonaga M, Golde D W, Gasson J C. Biosynthetic (recombinant) human granulocyte-macrophage colony stimulating factor: effect on normal bone marrow and leukemia cell lines. Blood 1986; 67: 31-6.

38 Nielsen O J, Andersen L S, Ludwigsen E, et al. Anaemia of rheumatoid arthritis: serum erythropoietin concentration and red cell distribution width in relation to iron status. Ann Rheum Dis 1990; 49: 349-53.

39 Takashina N, Kondo H, Kahiwazaka S. Suppressed serum erythropoietin response to anaemia and the efficacy of recombinant erythropoietin in the anaemia of rheumatoid recombinant erythropoietin in the anac
arthritis. $\mathcal{J}$ Rheum 1990; 17: 885-7.

40 Douglas $S \mathrm{~W}$, Adamson J W. The anaemia of chronic disorders: studies of marrow regulation and iron metabolism. disorders: studies of mar
Blood 1975; 45: 55-65. 